\title{
IDENTIFIKASI DAN TINGKAT SERANGAN PENYEBAB PENYAKIT BULAI DI LAMPUNG TIMUR, PESAWARAN, DAN LAMPUNG SELATAN
}

\author{
Adam Fajar Kurniawan, Joko Prasetyo \& Radix Suharjo \\ Jurusan Agroteknologi Fakultas Pertanian Universitas Lampung \\ Jl. Soemantri Brodjonegoro No.1 Bandar Lampung 35145 \\ E-mail: Jkdwiprasetyo21@gmail.com
}

\begin{abstract}
ABSTRAK
Penyakit bulai di Provinsi Lampung semula diidentifikasi disebabkan oleh satu spesies. Beberapa tahun terakhir ini laporan menyebutkan bahwa penyakit bulai pada tanaman jagung disebabkan oleh beberapa spesies Peronosclerospora.Penelitian ini bertujuan untuk mengetahui spesies Peronosclerospora.penyebab penyakit bulai pada tanaman jagung di tiga kabupaten di Provinsi Lampung dan untuk mengetahui persentase gejala, kerapatan, viabilitas spora bulai di tiga kabupaten tersebut. Penelitian dilaksanakan pada bulan Januari sampai dengan Juli 2016 di lahan pertanaman jagung milik petani dan di laboratorium hama dan penyakit tanaman Fakultas Pertanian Universitas Lampung. Pengamatan di lapangan dilakukan dengan menghitung insiden penyakit bulai di tiga kabupaten dengan cara mengambil 3 dari 30 baris tanaman jagung. Setiap daerah pengamatan terdiri dari dua lokasi pertanaman jagung yang berbeda sehingga terdapat enam lokasi yang berbeda-beda pada setiap kabupaten tersebut. Hasil penelitian menunjukkan bahwa penyakit bulai disebabkan oleh dua spesies yaitu Pernosclerospora sorghi, dan Peronosclerospora maydis.P. sorghi menyerang tanaman jagung di Kabupaten Lampung Timur dengan produksi spora sebesar $3,12 \times 10^{5}$ spora per $\mathrm{ml}$ dan viabilitas sebesar 35,67\% dengan insiden penyakit $19,33 \%$, spesies $P$. sorghi juga menyerang tanaman jagung di Kabupaten Pesawaran dengan produksi spora sebesar 3,22 x $10^{5}$ per ml dan viabilitas sebesar $35,67 \%$ dengan insiden penyakit $28,37 \%$. Kemudian P. maydis menyerang tanaman jagung di Kabupaten Lampung Selatan dengan produksi spora sebesar 3,07 x $10^{5}$ per ml dan viabilitas sebesar 35,60\% dengan insiden penyakit 28,37\%.
\end{abstract}

Kata Kunci: Bulai, Jagung, Peronosclerospora

\section{PENDAHULUAN}

Jagung merupakan tanaman pangan yang penting di Indonesia.Jagung menjadi sumber pangan pokok manusia ketiga setelah gandum dan padi. Jagung kaya akan karbohidrat, dan masih banyak kandungan gizi yang terdapat pada jagung diantaranya protein, lemak, kalori, fosfor, besi, vitamin A dan vitamin B1 (Lawton dan Wilson, 2003). Daerah sentra produksi jagung di Indonesia berada di Jawa Timur yang menyumbang $40 \%$ dari produksi nasional, diikuti Jawa Tengah, Lampung, Sulawesi Selatan, Nusa Tenggara, Sumatera Utara, Jawa Barat, dan Gorontalo. Salah satu kendala yang dihadapi dalam budidaya tanaman jagung adalah penyakit bulai (Anonim, 2011).

Provinsi Lampung merupakan salah satu daerah sentra produksi tanaman jagungdi Indonesia. Di Provinsi Lampung, jagung banyak ditanam di kabupaten LampungSelatan, Lampung Timur dan Lampung Tengah. Produksi jagung di Provinsi Lampung pada tahun 2016 sebesar 2 juta ton dan turun 12,60 persen dibanding produksi pada 2014 (Badan Pusat Statistik Lampung, 2016).
Menurunnya produksi jagung di Provinsi Lampung salah satunya disebabkan oleh penyakit bulai. Luas serangan penyakit bulai pada tahun 2010 mencapai 599 hektar dan pada tahun 2011meningkat menjadi 1.138 hektar (Balai Proteksi Tanaman Pangan dan Hortikultura Lampung, 2012).

Penyakit bulai di Provinsi Lampung semula disebabkan oleh satu spesies. Akhir-akhir ini beberapa laporan menyebutkan bahwa penyakit bulai pada tanaman jagung disebabkan oleh beberapa spesies Peronosclerospora, oleh karena itu perlu adanya konfirmasi mengenai berapa jumlah spesies dan bagaimana keragaman Peronosclerosporayang ada di Provinsi Lampung.

\section{BAHAN DAN METODE}

Penelitian dilaksanakan pada bulan Januari hingga Juni 2016 dengan menyurvei pertanaman jagung di tiga Kabupaten Provinsi Lampung, yaitu Lampung selatan, Pesawaran, dan Lampung Timur. Identifikasi dan karakterisasi penyakit bulai pada tanaman jagung dilakukan di Laboratorium Penyakit Tanaman, Jurusan 
Agroteknologi, Fakultas Pertanian, Universitas Lampung.

Bahan-bahan yang digunakan adalah tanaman jagung yang terserang penyakit bulai (Peronosclerospora spp.), benih jagung, aquades, media agar. Alat - alat yang digunakan di dalam penelitian ini adalahmikroskopstereo, kaca preparat, kaca preparat cekung, haemocytometer, cover glass, pipet tetes, jarum pentul, kuas, pinset, dan alat tulis. Penelitian ini dilaksanakan dengan melihat tingkat serangan di pertanaman jagung tiga kabupaten Provinsi Lampung kemudian dihitung persentase insiden penyakit bulai dengan rumus (Sekarsari, 2013) :

$$
\mathrm{KP}=\frac{n}{\mathrm{~N}} \times 100 \%
$$

Keterangan :

$\mathrm{KP}=$ Keterjadian penyakit

$\mathrm{n}=$ Jumlah tanaman terserang

$\mathrm{N}=$ Jumlah tanaman yang diamati

Identifikasi Penyebab Penyakit Bulai. Pengamatan dilakukan dengan mengambil konidia yang terdapat pada daun jagung dengan menggunakan jarum pentul secara perlahan kemudian diletakkan pada kaca preparat yang telah disediakan setelah itu dilakukan pengamatan di bawah mikroskop. Pengamatan Mikroskopis pada spora bulai diambil dari permukaan daun bagian lalu diletakkan di atas kaca preparat yang telah diteteskan air kemudian ditutup dengan cover glass,kemudian diamati secara mikroskopis.

Pengamatan Morfologi Konidia dan Konidiofor. dilakukan pada pukul 03.00 - 05.00 WIB, Pengamatan yang diamati meliputitebal konidia, panjang konidia, dinding sel, panjang konidiofor, panjang tangkai konidiofor, dan jumlahpercabangan (Gambar 1) (Rustiani et al., 2015).

Produksi Spora dilakukan dengan memotong daun jagung dengan ukuran $2 \times 2 \mathrm{~cm}$ (Gambar 2) sebanyak 2 helai, daun yang telah dipotong kemudian dipanen sporanya dengan cara menjepit daun tersebut dengan pinset di dalam cawan petri yang berisi air steril $5 \mathrm{ml}$ lalu spora tersebut dipanen dengan menggunakan kuas, kemudian spora di cawan petri tersebut diteteskan pada haemocytometer dan dihitung kerapatan pada 25 kotak sedang pada alat tersebut. Pengamatan dilakukan pada pukul 04.00 WIB - 06.00 WIB.Hasil dari kerapatan spora ini dihitung dengan rumus (Syahnenet al., 2014). :

$$
\mathrm{S}=\mathrm{R} \times \mathrm{K}
$$

Keterangan :

$\mathrm{S}=$ Jumlah Spora, $\mathrm{R}=$ Jumlah rata-rata spora pada 25 kotak pengamatan, $\mathrm{K}=$ Konstanta koefisien alat $(2,5 \mathrm{x}$ $\left.10^{5}\right)$

Viabilitas Spora. Pengamatan perkecambahan spora bulai dilakukan dengan cara memanen spora nya terlebih dahulu pada pukul 05.00 WIB dengan menggunakan kuas lalu di masukkan ke dalam botol vial yang sudah berisi air steril sebanyak $10 \mathrm{ml}$, kemudian botol yang sudah terisi spora bulai didiamkan di dalam kulkas pada suhu $8^{\circ} \mathrm{C}$ selama 5 jam. Perhitungan viabilitas spora dilakukan dengan menggunakan rumus (Gabriel dan Riyatno, 1989):

$$
\mathrm{V}=\frac{\mathrm{g}}{\mathrm{g}+\mathrm{u}} \times 100 \%
$$

Keterangan :

V: Viabilitas spora

$\mathrm{g}:$ Jumlah spora yang berkecambah

$\mathrm{u}$ : Jumlah spora yang tidak berkecambah

Pengamatan, Pengumpulan dan Analisis Data. Pengamatan dilapangan dilakukan seminggu sekali dengan menghitung insiden penyakit bulai yang menyerang pertanaman jagung, kemudian
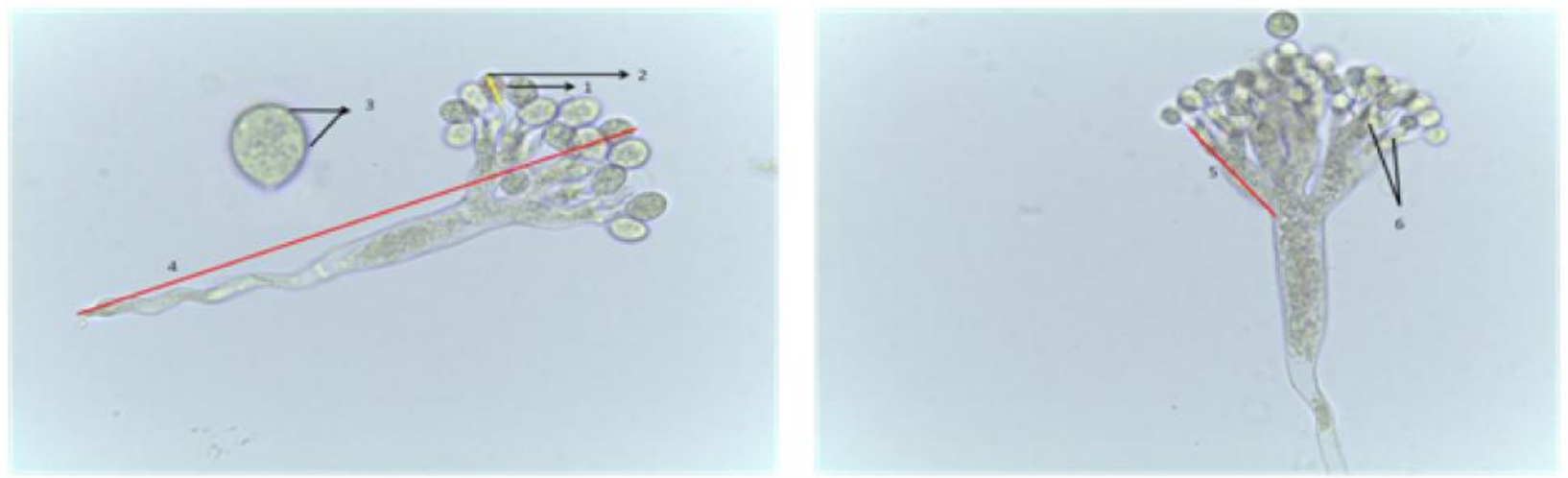

Gambar 1. Pengamatan Morfologi Konidia dan Konidiofor. (1) Tebal konidia, (2) Panjang konidia, (3) Dinding sel, (4) Panjang konidiofor, (5) Panjang tangkai konidiofor, (6) Jumlah percabangan. 
mengumpulkan data yang berkaitan dengan kerapatan dan viabilitas spora di tiga kabupaten, serta analisis data.

\section{HASIL DAN PEMBAHASAN}

Hasil Penelitian. Identifikasi Penyebab Penyakit Bulai. Hasil pengamatan Morfologi Konidia dan Konidiofor menunjukkan bahwa spesies Peronosclerospora yang menginfeksi tanaman jagung di daerah Lampung timur, Pesawaran, dan Lampung selatan secara morfologi berasal dari 2 spesies yaitu Peronosclerospora sorghi, dan Peronosclerospora maydis (Gambar 3). Ciri-ciri ketiga isolat tersebut disajikan pada Tabel 1. Kerapatan spora dua spesies Peronosclerospora yang berada pada kabupaten Lampung Timur, Pesawaran dan Lampung Selatan di tampilkan pada Tabel 2.

Hasil pengamatan menunjukkan bahwa kerapatan rata-rata spora di berbagai daerah berbeda-beda. Kerapatan spora paling tinggi terdapat pada daerah pesawaran yaitu 3,22 × $10^{5}$ spora per ml, diikuti oleh Kabupaten Lampung Timur dengan kerapatan spora 3,12 $\mathrm{x} 10^{5}$ spora per $\mathrm{ml}$ dan kerapatan spora pada Kabupaten Lampung Selatan yaitu 3,07 x $10^{5}$ spora per $\mathrm{ml}$. Tinggi atau rendahnya kerapatan spora ini diduga disebabkan oleh beberapa faktor antara lain faktor suhu, dan kelembaban.

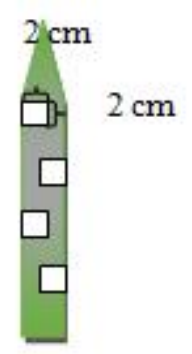

Gambar 2. Pemotongan daun jagung yang dipanen sporanya
Berdasarkan data hasil pengamatan (Tabel 3), rata-rata persentase perkecambahan spora pada masingmasing kabupaten berkisar antara 32,07\% - 35,67\%. Hasil pengamatan spora yang berkecambah ditampilkan pada Gambar 4. Hasil pengamatan menunjukkan bahwa persentase perkecambahan spora pada masing-masing daerah dan persentase perkecambahan paling tinggi yaitu pada Kabupaten Lampung Timur yaitu sebesar 35,67\%, diikuti dengan Kabupaten Lampung Selatan yaitu sebesar 35,60\% dan pada Kabupaten Pesawaran dengan jumlah persentase perkecambahan sebesar $32,07 \%$.

Pembahasan. Dari hasil pengamatan yang telah dilakukan, terdapat dua spesies Peronosclerospora yang menyerang tiga kabupaten di Provinsi Lampung yaitu $P$. sorghi pada kabupaten Lampung timur dan pesawaran, kemudian $P$. maydis pada Kabupaten Lampung Selatan. Hasil ini menunjukkan bahwa spesies P. sorghi mendominasi dari ketiga kabupaten tersebut. Rustiani et al. (2015) melaporkan bahwa spesies yang menyerang pertanaman jagung di Provinsi Lampung terdapat tiga spesies $P$. sorghi, $P$. phillipinensis, dan $P$. maydis. Hasil pengamatan tidak ditemukan spesies yang menunjukkan ciri-ciri dari $P$. phillipinensis tetapi hanya didapatkan dua ciri-ciri spesies peronosclerospora saja. Laporan keberadaan $P$. maydis dan P. sorghi di Provinsi Lampung juga telah dilaporkan oleh Widiantini et al. (2015), Muis et al. (2013), Wakman dan Djatmiko (2002).

Produksi spora di tiga kabupaten yang diamati terlihat memiliki perbedaan yang tidak signifikan berkisar antara 3,07-3,22 x $10^{5}$ spora per ml. Dalmacio dan Raymundo, 1972; Bonde (1982) melaporkan bahwa produksi spora peronosclerospora membutuhkan kelembaban yang tinggi, setidaknya terdapat lapisan air yang tipis selama 4-5 jam pada permukaan daun yang terinfeksi. Infeksi yang terjadi pada malam hari membutuhkan kisaran suhu $21-26^{\circ} \mathrm{C}$. Jumlah tanaman yang terinfeksi berkorelasi positif dengan kelembaban dalam waktu yang relatif singkat (Bondeet al.,1982).

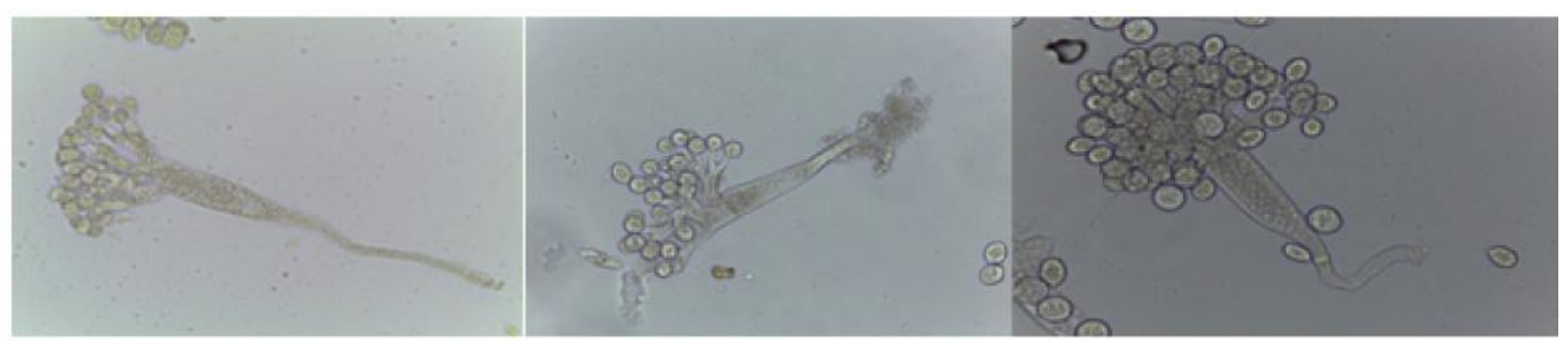

Gambar 3. Hasil pengamatan morfologi peronosclerospora (a) Struktur Morfologi Peronosclerospora sorghi, (b) Struktur Morfologi Peronosclerospora sorghi, (c) Peronosclerospora maydis(400X). 
Tabel 1. Karakterisasi morfologi Peronosclerospora dengan kunci identifikasi mengacu pada artikel Rustiani et al.

\begin{tabular}{|c|c|c|c|}
\hline Isolat Lokasi & Hasil Pengamatan & $\begin{array}{l}\text { Pustaka Rustiani, et al } \\
\text { (2015) }\end{array}$ & $\begin{array}{l}\text { Identitas } \\
\text { (Spesies) }\end{array}$ \\
\hline Pesawaran & & & P. Sorghi \\
\hline - Jumlah Percabangan & 2 & 2 & \\
\hline - Panjang Konidiofor & $215-229 \mu \mathrm{m}$ & $183-300 \mu \mathrm{m}$ & \\
\hline - Diameter Konidia & $9,5-10 \times 10-11 \mu \mathrm{m}$ & $9-10 \times 10-11 \mu \mathrm{m}$ & \\
\hline - Tebal Dinding Konidia & $1,54 \mu \mathrm{m}$ & $1-2 \mu \mathrm{m}$ & \\
\hline Lampung Timur & & & P. sorghi \\
\hline - Jumlah Percabangan & 2 & 2 & \\
\hline - Panjang Konidiofor & $190-229 \mu \mathrm{m}$ & $183-300 \mu \mathrm{m}$ & \\
\hline - Diameter Konidia & $9,7-10 \times 10,9-11 \mu \mathrm{m}$ & $9-10 \times 10-11 \mu \mathrm{m}$ & \\
\hline - Tebal Dinding Konidia & 1,26 & $1-2 \mu \mathrm{m}$ & \\
\hline Lampung Selatan & & & P. Maydis \\
\hline - Jumlah Percabangan & 3 & 3 & \\
\hline - Panjang Konidiofor & $191-300 \mu \mathrm{m}$ & $111-410 \mu \mathrm{m}$ & \\
\hline - Diameter Konidia & $18,8-22 \times 26,9-40 \mu \mathrm{m}$ & $12-23 \times 25-44 \mu \mathrm{m}$ & \\
\hline - Tebal Dinding Konidia & $0,69 \mu \mathrm{m}$ & $<1 \mu \mathrm{m}$ & \\
\hline
\end{tabular}

Tabel 2. Kerapatan spora tiga daerah yang mewakili pada tiap-tiap kabupaten

\begin{tabular}{cc}
\hline Daerah & Kerapatan Spora per ml \\
\hline Lampung Timur & $3,12 \times 10^{5}$ \\
Pesawaran & $3,22 \times 10^{5}$ \\
Lampung Se latan & $3,07 \times 10^{5}$ \\
\hline
\end{tabular}

Tabel 3. Viabilitas spora pada suhu $8^{\circ} \mathrm{C}$

\begin{tabular}{cc}
\hline Kabupaten & Rata-rata Persentase Perkecambahan Spora (\%) \\
\hline Lampung Timur & $35,67 \%$ \\
Pesawaran & $32,07 \%$ \\
Lampung Se latan & $35,60 \%$ \\
\hline
\end{tabular}

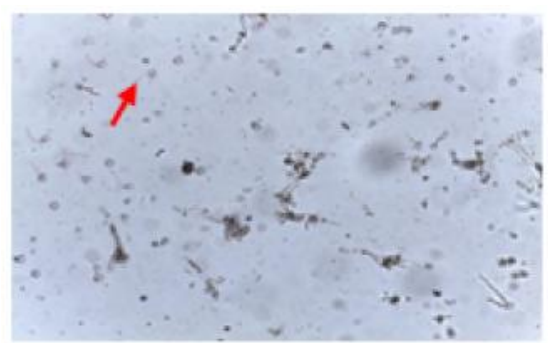

Gambar 4. Buluh kecambah konidia P. sorghi (anak panah) (100X)

Persentase viabilitas spora dipengaruhi oleh suhu. Menurut Bonde et al. (1978) isolat peronosclerospora dari Amerika membutuhkan kisaran suhu untuk perkecambahan konidia ialah $10-33^{\circ} \mathrm{C}$ dan waktu minimal 4 jam. Hasil ini berbeda jika dibandingkan dengan hasil pengamatan yang telah dilakukan pada tiga kabupaten yang hanya membutuhkan suhu $8^{\circ} \mathrm{C}$ yang di inkubasikan di dalam kulkas selama 5 jam.

Persentase insiden penyakit paling besar terlihat di daerah Pesawaran (28,37\%), Kabupaten Lampung Selatan $(28,06 \%)$, dan yangpaling rendah yaitu Kabupaten Lampung Timur (12\%). Insiden penyakit di Kabupaten Pesawaran diduga dipengaruhi olehmedia (lokasi) pertanaman.Lokasi pertanaman yang digunakan memiliki riwayat pada musim tanam sebelumnya sudah pernah terinfeksi peronosclerospora, sehingga saat dilakukan penanaman kembali patogen tersebut masih ada dan menyerang tanaman jagung yang dibudidayakan.Peronosclerospora umumnya bertahan hidup pada gulma yang ada di lingkungan budidaya. Hal ini di dukung dengan laporan Rani dan Raju dalam 
Sudarma et al. (2012) bahwa gulma dapat menjadi salah satu sumber untuk peronosclerospora bertahan hidup.

Persentase tanaman terinfeksi berpengaruh terhadap hasil produksi (Bondeet al.,1982).Semakin banyak tanaman yang terinfeksi maka hasil yang diperoleh petani semakin rendah.Tanaman terinfeksi memiliki intensitas serangan yang beragam, hal ini didukung dengan laporan Soenartiningsih dan Talanca (2010), bahwa setiap varietas bervariasi intensitas serangannya. Pada varietas NK 22 intensitas serangan bisa mencapai 30-90\% tergantung umur tanaman dan pada bulan apa dilakukan penanaman.

\section{KESIMPULAN}

Berdasarkan studi morfologi yang dilakukan terdapat 3 spesies Peronosclerospora yang menyerang tanaman jagung di Provinsi Lampungyaitu P. sorghi pada Kabupaten Lampung Timur, dan Pesawaran, kemudian P.maydis pada Kabupaten Lampung Selatan.Spesies yang menyerang tanaman jagung di Kabupaten Lampung Timur ( $P$. sorghi) menyebabkan insiden penyakit sebesar $19,33 \%$ dengan produksi spora sebesar 3,12 x $10^{5}$ spora per $\mathrm{ml}$ dan viabilitas sebesar $35,67 \%$. Selanjutnya pada spesies Kabupaten Pesawaran (P. sorghi) menyebabkan insiden penyakit sebesar $28,37 \%$ dengan produksi spora sebesar $3,22 \mathrm{x}$ $10^{5}$ spora per $\mathrm{ml}$ dan viabilitas sebesar $32,07 \%$. Kemudian pada spesies Kabupaten Lampung Selatan (P. maydis) menyebabkan insiden penyakit sebesar $28,06 \%$ dengan produksi spora $3,07 \times 10^{5}$ spora per $\mathrm{ml}$ dan viabilitas sebesar $35,60 \%$.

\section{DAFTAR PUSTAKA}

Anonim. 2011. Deskripsi varietas unggul jagung, sorgum dan gandum. Balai PenelitianTanaman Serealia, Badan Penelitian dan Pengembangan Pertanian, PusatPenelitian dan Pengembangan Tanaman Pangan. 34 hlm

Badan Pusat Statistik Lampung (BPS). 2012. Laporan Tahunan Balai Proteksi Tanaman Pangan dan Hortikultura. Provinsi Lampung.

Balai Proteksi Tanaman Pangan dan Hortikultura. 2012. Laporan UPTD Balai Proteksi Tanaman Pangan dan Hortikultura. Provinsi Lampung.

Bonde M.,R., Peterson G.,L., Kenneth R.,G., Vermeulen H.,D., Sumartini and Bustaman M., 1982. Effect of temperature on conidial germination and systemic infection of maizeby Peronosclerospora species. Phytopathology, 82: 104-109.

Dalmacio, S.C. and Raymundo, A.D. 1972. Spore density of Sclerospora philippinensis in relation to field temperature, relative humidity, and downy mildew incidence. Philippine Phytopathology 8: 72-77.

Gabriel B., Riyatnoo P., 1989. Metharizium anisopliae (Meetsch) Sor. Taksonomi, patologi,produksi dan aplikasinya. Proyek Pengembangan Perlindungan Tanaman Perkebunan, Departemen Pertanian, Jakarta.

Lawton J.W., and C.M. Wilson. 2003. Proteins of the kernel. In: White PJ., Johnson LA., editor. Corn: Chemistry and Technology. Ed ke-2. Minnesota:American Association Of Cereal Chemists Inc. St. Paul, Minnesota, USA. 313354.

Muis, A., Pabendon, M., B., Nonci, N., Waskito, W.,P.,S. 2013. Keragaman Genetik Peronosclerospora maydisPenyebab Bulai pada Jagung Berdasarkan Analisis Marka SSR.Jurnal Penelitian Pertanian Tanaman Pangan.32: 139-147.

Rustiani, U.S., Sinaga, M., S., Hidayat, S.,H., dan Wiyono, S. 2015. Tiga Spesies Peronosclerospora Penyebab Penyakit Bulai Jagung di Indonesia. Jurnal Berita Biologi. 14(1): 29-37.

Sekarsari, 2013.Pengaruh Beberapa Fungisida Nabati Terhadap Keterjadian Penyakit Bulai pada Jagung (Zea mays saccharata). Jurnal Agrotek Tropika. 1(1): 98 - 101

Semangun, H. 1993. Penyakit-Penyakit Tanaman Pangan di Indonesia. (Food crop diseases in Indonesia).Gadjah Mada University Press.449 hlm.

Soenartiningsih dan Talanca,A. H. 2010. Prosiding Seminar Ilmiah dan Pertemuan Tahunan PEI dan PFI XX Komisariat Daerah Sulawesi Selatan, Makassar 27 Mei 2010 . Hal 42-46.

Sudarma, I.M., Suada, I.K. Yuliadh, K.A, dan Puspawati N.M. 2012. Hubungan Antara Keragaman Gulma Dengan Penyakit Bulai Pada Jagung (ZeaMays L.) Stadium Pertumbuhan Vegetatif. Agrotrop 2: 91-99.

Syahnen, Desianty, D.N.S., Sry, E. dan Pinem. 2014. Teknik uji mutu agens 
pengendalian hayati (APH) di Laboratorium. http:/ /ditjenbun.pertanian. go.id/ bbpptpmedan/ berita-279- teknik-uji- mutuagens-pengendalihayati-aph-di-laboratorium.html.Diunduh pada tanggal 14 Mei 2015.

Talanca, A, H. 2013.Status Penyakit Bulai Pada Tanaman Jagung dan Pengendaliannya.Balai Penelitian Tanaman Serealia. Hal 76-87.

Wakman, W., dan Djatmiko, H.A. 2002. Sepuluh Spesies Cendawan Penyebab Penyakit bulai pada
Tanaman jagung. Makalah Seminar Perhimpunan Fitopathologi Indonesia (PFI). Universitas Soedirman Purwokerto, 7 September 2002. Hal 100-104.

Widiantini, F., Yulia, E., dan Purnama, T. 2015.Morphological Variation of Peronosclerospora maydis, The Casual Agent of Maize Downy Mildew from Different Locations in Java Indonesia. Journal of Agricultural Engineering and Biotechnology.3: 58-62. 